\title{
Het budget op de korrel
}

\author{
Tom Groot
}

In deze periode van het jaar zijn in de meeste organisaties de uitgangspunten en richtlijnen voor debegroting $2007 \mathrm{al}$ uitgevaardigd. Afdelingschefs, divisiehoofden en managers van businessunits breken zich nu het hoofd over een passend antwoord. Hoe kan een goede bijdrage worden

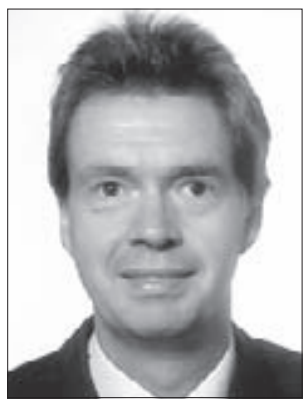
geleverd aan het beleid van de gehele organisatie en tegelijkertijd voldoende ruimte voor de eigen afdeling worden gecreëerd? Sommigen zien het budgetteringsproces als een jaarlijks bestuurlijk hoogtepunt, waarin strategisch inzicht, financieel-economische planning, en tactisch vernuft een meerwaarde voor het organisatieonderdeel moeten opleveren. Anderen zien het budgetteringsproces als een geldverslindend, bestuurlijk ritueel met voorspelbare afloop. Zij vragen zich af wat de budgettering eigenlijk nog toevoegt aan het functioneren van een organisatie: zouden veel bedrijven eigenlijk niet net zo goed werken zónder deze bestuurlijke folklore? Recent onderzoek geeft aan dat slechts een kwart van de Nederlandse managers tevreden is met de huidige budgetteringspraktijk, ruim eenderde vindt budgettering een verspilling van tijd en geld, terwijl de rest de budgettering wil verbeteren. Veel bedrijven hebben hun budgettering op de korrel en de uitslag van deze heroverweging lijkt allerminst zeker.

Budgettering heeft ook nogal wat nadelen. Het is een tijdrovend proces (managers besteden gemiddeld 30\% van hun tijd aan budgetteren), dat zich vooral richt

Prof. dr. T.L.C.M. Groot is hoogleraar Management Accouting aan de faculteit Economie en Bedrijfskunde van de Vrije Universiteit te Amsterdam. op financieel-economische doelstellingen zonder de belangrijke strategische kwesties centraal te stellen. De uitkomst van budgetonderhandelingen zijn veelal statische prestatienormen en bijbehorende budgetten die niet snel worden herzien. Dit werkt verstarring in de hand: budgethouders richten zich vooral op de budgetnormen en houden daardoor minder rekening met veranderde omstandigheden. Starre budgetnormen kunnen ook spontane samenwerking tussen bedrijfsonderdelen in de weg staan. Ten slotte kennen we allemaal de disfunctionele, manipulatieve gedragingen van budgethouders om ervoor te zorgen dat zij aan het einde van de budgetperiode een goed eindresultaat kunnen presenteren. Die gedragingen betreffen het inbouwen van 'slack' (extra financiële armslag) in het budget door een verkeerde voorstelling te geven van de eigen mogelijkheden en beperkingen, het bekende "opmaak-gedrag" aan het einde van een budgetperiode, een overdreven budgetgericht gedrag tijdens de taakuitvoering, en het manipuleren van budgetgerelateerde financiële rapportages. Mocht $\mathrm{u}$ enkele van deze nadelen herkennen en hier iets aan willen doen, dan hebt u globaal gesproken drie opties:

- u verbetert stapsgewijs en op enkele onderdelen de huidige budgettering;

- u gooit al uw energie in een geheel vernieuwd budgetteringssysteem; of

- $\mathrm{u}$ houdt gewoon op met budgetteren en gaat iets "geheel anders" doen.

Aanhangers van deze laatste optie behoren bij de "Beyond Budgeting"-beweging: een door het Consortium for Advanced Manufacturing-International (afgekort CAM-I) bedachte term, die zoiets betekent als "verder dan budgettering". Waaruit dat "verder dan" bestaat wordt niet helemaal duidelijk. Model staat de Zweedse Handelsbanken: een bank waarin de budgettering al in de jaren zeventig is afgeschaft en die sindsdien uiterst succesvol is gebleken. De legen- 
darische manager Jan Wallander die de budgettering bij het oud vuil heeft gedaan bestuurt zijn bedrijf sindsdien op basis van een interne competitie tussen de bankfilialen. De bedoeling is simpelweg om de beste te zijn op het gebied van marktomvang, rendement en winst. Hierdoor zijn er geen vaste normen meer nodig: de fundamentele opdracht is anderen te verslaan, het speelveld wordt bepaald door de concurrentie buiten de bank. Het budget van elk filiaal is uitgedrukt in een percentage van de omzet - op die manier is budgetteren eigenlijk niet nodig: hoe groter een filiaal wordt, des te meer geld er ter beschikking komt. Geld dat overigens zelf wordt verdiend. De vraag is echter of dit systeem in alle organisaties kan worden ingevoerd: niet alle bedrijven bestaan uit gelijkvormige eenheden die op een transparante markt opereren. De Beyond Budgeting-aanhangers zien hierin geen probleem: elke organisatie zou Beyond Budgeting moeten worden. Kijken we echter naar de praktijkvoorbeelden die deze adepten ons voorschotelen, dan blijkt dat elke organisatie toch weer haar eigen oplossing zoekt. Sommige oplossingen staan zelfs mijlenver verwijderd van de Zweedse Handelsbanken! Enige scepsis is hier dus geboden: de aanhangers van de Beyond Budgeting-beweging zijn van kritische denkers over budgettering langzaamaan verworden tot apostelen van de Beyond Budgetingdoctrines.

Wat doen bedrijven eigenlijk die zeggen hun budget te hebben afgeschaft? Sommige van hen schakelen over op een systeem van rolling forecasts die met wisselende frequentie worden herzien. Andere maken hun budgettering meer strategisch door er meer nietfinanciële doelstellingen in op te nemen. De meeste voorbeeldbedrijven maken gebruik van benchmarking: zowel tussen onderdelen binnen de eigen organisatie als met andere bedrijven. Deze benaderingen komen eigenlijk meer in de buurt van de eerste optie: geen afschaffing maar een op enkele punten verbeterde budgettering. Hierdoor blijft eigenlijk de tweede optie nog onbesproken: het drastisch vernieuwen van de budgettering. Ook bij deze optie komen we CAMI tegen. Een andere groep binnen dit consortium van bedrijven en wetenschappers heeft zich de afgelopen jaren toegelegd op een vernieuwd budgetteringssysteem en heeft het Activity-based Budgeting (ABB) concept ontwikkeld. Het woord zegt het eigenlijk al: het is een bijproduct van Activity-based Costing. Deze benadering begint op dezelfde wijze als de traditionele budgettering, namelijk met een inschatting van de marktvraag. Vervolgens wordt de benodigde productiecapaciteit bepaald en de middelen die voor produceren moeten worden gereserveerd. Hierbij kan dankbaar gebruik worden gemaakt van (reeds aanwezige) ABC-informatie over activiteiten en verbruik per product. Operationele plannen kunnen nu worden opgesteld door aard en aantal activiteiten per product aan te passen aan de nieuwe omstandigheden en strategische beslissingen. Pas in een later stadium wordt aansluiting gezocht bij de financiële planning door het gebruik van costdrivers. Mochten de operationele uitkomsten niet in balans zijn met de financiële doelstellingen, dan kan men op vijf manieren proberen deze balans te herstellen: door de productiecapaciteit aan te passen (investeringen en desinvesteringen), door niveau en aard van activiteiten te veranderen (slimmer te produceren), door het productievolume aan te passen (risico van neen-verkopen nemen), door goedkoper in te kopen en door de verkoopprijs aan te passen. Hier wordt de nieuwe benadering zichtbaar: ABB richt zich veel meer op de operationele activiteiten van de budgethouders en poogt hiermee de financiële planning dichterbij de dagelijkse uitvoeringspraktijk te brengen.

Nederlandse bedrijven blijken in de recente periode al veranderingen in hun budgettering te hebben aangebracht. Veel ondernemingen doen pogingen het budgetteringsproces te bekorten - met overigens sterk wisselend resultaat. Daarnaast blijkt budgettering al meer strategiegericht dan louter financieel van aard te zijn: veel organisaties stellen ook strategische, niet-financiële doelstellingen in het budgetproces. Bovendien blijkt de helft van Nederlandse bedrijven de normen die bij de budgettering zijn gebruikt vaker te herzien dan eens per jaar. Ongeveer tien procent van de bedrijven stelt de begrotingsnormen zelfs continu bij, dat wil zeggen zodra nieuwe informatie daar aanleiding toe geeft. En hiermee komen we eigenlijk vooral uit bij het eerste alternatief: die van de stapsgewijze verbetering van de budgettering. Een al te drastische afschaffing van budgettering was in Nederland ook niet te verwachten - daar zijn we misschien iets te nuchter voor. Die nuchterheid heeft overigens wel het resultaat dat we budgettering niet alleen behouden, maar ook aanpassen voor de nieuwe tijd. Dit lijkt me dubbel winst. 